\title{
Üniversite Öğrencilerinin E-Öğrenmeye Hazır Bulunuşluklarının İncelenmesi: Bartın Üniversitesi Örneğï
}

Ramazan Yılmaz $^{* * 1}$, Barış Sezer $^{2}$ ve Halil Yurdugül ${ }^{3}$

\section{Öz}

Anahtar Sözcükler

$\mathrm{Bu}$ araştırmanın amacı Bartın Üniversitesi’nde bir ve son sınıflarda öğrenim gören öğrencilerin eöğrenmeye hazır bulunuşluk düzeylerini ve bunun üzerinde etkili olan faktörleri belirlemektir. Araştırmada tarama modeli kullanılmıștır. Araștırmanın katılımcıları birinci ve son sınıftaki 5021 öğrencidir. Veri toplama aracı olarak demografik bilgiler formu ve altı faktör ve 33 maddeden oluşan eöğrenmeye hazır bulunuşluk ölçeği kullanılmıştır. Araştırma sonucunda ölçek geneli için öğrencilerin hazır bulunuşluk düzeylerinin yüksek düzeyde olduğu, alt boyutlar açısından bakıldığında bilgisayar özyeterliği ve e-öğrenmeye yönelik motivasyon alt boyutlarında orta, kendi kendine öğrenme, çevrimiçi iletişim öz-yeterliği, internet öz-yeterliği ve öğrenen kontrolü alt boyutlarında yüksek düzeyde olduğu belirlenmiştir. Ayrıca erkek öğrencilerin e-öğrenme hazır bulunuşluklarının kadın öğrencilere göre, son sınıf öğrencilerinin birinci sınıftaki öğrencilere göre, kişisel bilgisayar sahip olan öğrencilerin olmayanlara göre, internet bağlantısı olan akıllı telefona sahip olan öğrencilerin olmayanlara göre daha yüksek düzeyde olduğu bulunmuştur. Araştırmanın diğer bir bulgusuna göre öğrencilerin öğrenim gördükleri fakülteye/yüksekokula göre e-öğrenmeye hazır bulunuşluk puan ortalamaları arasında farklılıkların olduğu belirlenmiştir. Araştırmadan elde edilen bulgular doğrultusunda çeşitli önerilerde bulunulmuştur.

E-öğrenme

Yükseköğretim

Hazır bulunuşluk

Kendi kendine öğrenme

Öz-yeterlik

Makale Hakkında

Gönderim Tarihi

17 Mayıs 2018

Kabul Tarihi

24 Haziran 2019

Makale Türü

Araştırma Makalesi

DOI: 10.12984/egeefd.424614

\section{Investigation of University Students E-Learning Readiness: Example of Bartın University}

\section{Abstract}

The aim of the current study was to determine the level of readiness of e-learning students at Bartın University who were in the first or last year of their studies. It was also aimed to identify the variables that influence students' e-learning readiness. The survey model was used in this research. Participants of the study were students who were enrolled in bachelor or associate degree programs $(N=5021)$. The data collection instrument was the demographic information form and the e-learning readiness scale of university students consisting of six factors and 33 items. As a result, it was determined that the level of e-learning readiness of the students was high. When the sub-dimensions were examined, computer selfefficacy and motivation for e-learning were moderate. Self-directed learning, online communication selfefficacy, Internet self-efficacy, and learning control were found to be at high levels. It was also found that the e-learning readiness levels of male students were higher than female students. Another finding was a statistically significant difference among students' e-learning readiness levels based on grades and this difference was found to be in favor of last year students. It was observed that e-learning readiness levels of students who owned a computer and those who owned a smart phone were higher. There was also a difference between the mean of e-learning readiness according to faculty / college in which students were enrolled. Various suggestions were made in line with the findings of the study.

\section{Keywords}

E-learning

Higher education Readiness

Self-directed learning Self-efficacy

Article Info

Received

May 17, 2018

Accepted

June 26, 2019

Article Type

Research Paper

Atıf: Yılmaz, R., Sezer, B. ve Yurdugül, H. (2019). Üniversite öğrencilerinin e-öğrenmeye hazır bulunuşluklarının incelenmesi: Bartın Üniversitesi örneği. Ege Eğitim Dergisi, 20(1), 180-195. doi: 10.12984/egeefd.424614

\footnotetext{
* Bu çalışma Bartın Üniversitesi Bilimsel Araştırmalar Proje Birimi tarafindan desteklenen 2017-SOS-A-002 kodlu araştırma projesinden üretilmiştir. [This study was produced from a research project (\#2017-SOS-A-002) supported by the Bartin University Scientific Research Project Unit]

Bu çalışma, 02-04 Mayıs 2018 tarihleri arasında İzmir'de düzenlenen 12. Uluslararası Bilgisayar ve Öğretim Teknolojileri Sempozyumunda sunulmuştur. [This study was partly presented at the $12^{\text {th }}$ International Computer and Instructional Technologies Symposium in İzmir, May $02-04,2018]$

Sorumlu Yazar/Corresponding Author

1 (D) Bartın Üniversitesi, Eğitim Fakültesi, Bilgisayar ve Öğretim Teknolojileri Eğitimi Bölümü, Türkiye, ramazanyilmaz067@ gmail.com

2 (D) Hacettepe Üniversitesi, Tıp Fakültesi, Temel Tıp Bilimleri Bölümü, Tıp Eğitimi ve Bilişimi Ana Bilim Dalı, Türkiye, barissezer13@hotmail.com

3 Hacettepe Üniversitesi, Eğitim Fakültesi, Bilgisayar ve Öğretim Teknolojileri Eğitimi Bölümü, Türkiye, yurdugul@hacettepe.edu.tr
} 


\section{Extended Abstract}

\section{Introduction}

E-learning readiness is one of the 10 sub-dimensions of e-learning (planning, readiness, management, support, pedagogy, technology, faculty, institution, evaluation, and ethics). Determining what kind of support students need in the e-learning process seems to be very important in terms of developing preventive / supportive interventions and ensuring institutional success in this direction. In this context, the purpose of the study was to identify the level of e-learning readiness of first and last year class students at Bartın University and the factors that influence it.

Effective e-learning practice requires the effective integration / handling of many elements: training and skills of trainers, characteristics and needs of learners, management, infrastructure, technical support, expected learning outcomes, cultural / social factors, and the educational approach to achieve learning outcomes (Persico, Manca, \& Pozzi, 2014; Tarhini, Hone, Liu, \& Tarhini, 2017). The continuity of learner participation is the most important factor in the success of these practices (Limayem \& Cheung, 2008; McGill, Klobas, \& Renzi, 2014). Learners should know that e-learning will meet their educational needs and expectations. Determining which students need more support at the beginning of the e-learning process is crucial to be able to develop preventive / supportive interventions (Harman \& Çelikler, 2012).

When the literature is reviewed, there are many studies on the necessity of measuring the readiness of the students for an effective implementation of e-learning (Hung, Chou, Chen, \& Own, 2010; Oliver, 2001; Moftakhari, 2013). Determining the readiness of university students to learn about e-learning will guide the researchers and e-learning practitioners and decision-makers in e-learning field on how to prepare students for elearning. The existing research on the university students' readiness for e-learning are mostly conducted on the students studying in a certain faculty / college such as the faculty of education. However, it is possible to identify generalizability of research results and to compare readiness status of students for e-learning by making comparisons on the basis of faculties / colleges, and thus to be able to make comparisons and prepare unit-based needs analysis reports. In this way, unit based needs analysis will be introduced and it will be possible to make updates in the curriculums of units for the elimination of this need and to take measures to develop unit based institutional infrastructure. For this reason, it was aimed to contribute to the literature by comparing with faculties / colleges. It will also be possible to determine the extent to which units' curricula function in making students ready for e-learning by making comparisons at the year level (comparison of first and final year students). Therefore, comparisons based on the year spent in university was also included in current research. It is important to identify whether individual differences are effective on readiness of individuals for e-learning.

It is essential to take measures to increase readiness of students for e-learning in accordance with individual differences. Therefore, the existing research supports that the students' status on owning personal computer and smartphone as well as having internet facilities make a significant difference on their e-learning readiness. One of the individual differences investigated within the scope of the research is the gender variable. When the literature is surveyed, it is stated that the gender variable can have an effect on the behaviours, beliefs and attitudes of individuals about technology (Karaoğlan Yılmaz \& K1lıç Çakmak, 2016). Whether or not gender will lead to a significant difference on the readiness of e-learning is another point of interest. The aim of this study, which is based on the reasons explained above, is to determine the level of readiness of university students for elearning.

\section{Method}

The survey model was used in the study. Participants of the study are first and last year students who were studying at Bartın University. In this context, 5021 students voluntarily participated in the research. The data collection instrument was the demographic information form and the e-learning readiness scale of university students consisting of six factors and 33 items. The Cronbach Alpha reliability coefficient of the scale was .94.

At the beginning of the research period, the number of students studying in the first and last year was determined. Then optical forms were prepared for each student. Lastly, research data was obtained by administering these optical forms to students who volunteered to participate in the research. Descriptive statistics such as percentage, frequency, mean, and standard deviation were calculated in the analysis phase. Skewness and kurtosis values were checked to control the normality and homogeneity assumption of data. Mann-Whitney U and Kruskal Wallis Test were applied when the data were not normally distributed. The level of significance in the study was accepted as .05 . 


\section{Findings}

As a result of the research, it was determined that the level of e-learning readiness of the students for the scale is high. When the sub-dimensions are examined, it is seen that the dimensions of computer self-efficacy and motivation for e-learning are moderate. Self-directed learning, online communication self-efficacy, Internet selfefficacy and learning control were found to be at high levels. It was also found that the e-learning readiness levels of male students were higher than female students. It was found that there was a statistically significant difference among students' e-learning readiness levels based on the year spent in university and this difference was found to be in favor of last year students. It is observed that e-learning readiness levels of students who owned a computer or smart phone were higher. According to another finding of the research, it was determined that there is a difference between the means of e-learning readiness according to faculty / college enrolled. Results were discussed in terms of what can be done in order to improve the readiness level of students for elearning in the direction of the findings obtained from the research.

\section{Discussion and Conclusion}

This research is important in terms of contributing to the generalizability of the research results related to the elearning readiness of university students. In the current research, readiness of the students in the units of faculties / colleges in terms of e-learning is compared, and the results of the research reveal a unit-based needs analysis report. In this context, it is necessary to make updates in the curriculum of the related units according to the needs of the students to improve the infrastructure facilities and to increase the readiness of the students. In this context, measures should be taken by the practitioners and decision makers by taking the results of the research into consideration. 


\section{Giriş}

Yüksek kalitede eğitim/öğretim faaliyetlerinin gerçekleştirilmesi; eğitim pedagojisinin iyi/güçlü bir şekilde anlaşılmasına bağlı olduğu gibi, bu doğrultuda son teknolojik gelişmelerin öğrencilerin öğrenmesinde etkili/verimli biçimde kullanması ile de yakından ilişkilidir (Agbo, 2015). Günümüzde özellikle mobil teknolojilerin kullanımının yaygınlaşması ile beraber elektronik öğrenme (e-öğrenme) kavramı giderek önem kazanmaya başlamış ve sınıf içi ve sınıf dışı öğretim uygulamalarının yürütülmesinde e-öğrenme önemli bir rol kazanmıştır. E-öğrenme, öğrenme içerik ve materyallerinin elektronik ortamda sunulması ile gerçekleştirilen bir öğrenme etkinliği olup, öğrenciler elektronik ortamda çeşitli öğrenme deneyimleri yaşayabilmektedir. Eöğrenme ile öğrenciler istenilen yer ve zamanda öğrenme içerik ve materyallerine erişebilmekte, diğer öğrenciler ve öğretmenleri ile etkileşim kurabilmektedir. Günümüzde e-öğrenme ortamları nitelikli öğrenci-içerik, öğrenciöğretmen ve öğrenci-içerik etkileşimlerinin gerçekleşebilmesi için birçok firsat sunmaktadır.

E-öğrenme özellikle internet teknolojilerinin yaygınlaşması ile birlikte yüksek eğitim kurumlarında giderek yaygın biçimde kullanılmaktadır (Ansong, Boateng ve Boateng, 2017; Goh, 2016; McConnell, 2017; Yılmaz, Sezer ve Yurdugül, 2018). Bu yaygın kullanım maliyeti azaltmada, öğrencilerin ilgilerini artırmada ve onların eğitsel gereksinimlerini karşılamada kolaylaştıııcı faktör olmaktadır (Arpaci, 2015). Gerçekleştirilen bir araştırmada (Allen ve Seaman, 2013) yükseköğretim kurumlarının \% 69'unun e-öğrenme sistemlerini kullandıkları ve uzun dönemli eğitsel başarıda bu durumun en önemli yapı taşı olduğuna inandıkları belirlenmiş̧tir. Ambient Insight araştırma raporuna göre Asya, Afrika ve Orta Doğu ülkelerinde daha hızlı olmakla birlikte, dünya çapında e-öğrenme sistemlerine yapılan yatırım 2010 yılında 32 milyar dolar iken, 2015 yılında 47 milyar dolar seviyelerine ulaştı̆̆ bildirilmiş olup, bu hızın her sene yüzde 8 olarak devam etmesi öngörülmektedir (Ambient Insight, 2016). Bu durum yaşam boyu öğrenme bağlamında etkili öğrenmenin desteklenmesinde üniversitelerin e-öğrenme kurumlarına dönüşmesini beraberinde getirmektedir. Bu bağlamda Kitlesel Açık Çevrimiçi Ders-KAÇD (Massive Open Online Course-MOOC) yaşam boyu öğrenme perspektifinde sıklıkla kullanılmaya başlanmışıı. Internet yoluyla geniş kitlelere erişerek, eğitsel içeriği videolar, yazılı materyaller, forum vb. yoluyla öğrenenlerle paylaşıma olanak tanıyan KAÇD’ler herkese açıktır, akran/öğrenen temelli öğrenme esasına dayanır (Burd, Smith ve Reisman, 2015). Bireyler ihtiyaçlarına göre herhangi bir KAÇD uygulamasına dâhil olabilmektedir. $\mathrm{Bu}$ sistemler genellikle üniversitelerin çeşitli kurum/kuruluşlarla işbirliği ile geliştirilmektedir (Hew ve Cheung, 2014). Amerika Birleşik Devletleri ve Avustralya'da bu sistemlerin sıklıkla kullanıldığı ve eğitim maliyetlerinde çok ciddi bir düşüşe neden olduğu bildirilmektedir (Yuan ve Powell, 2013). Bu bulguyu destekler nitelikte Çin'de e-öğrenmenin yaşam boyu öğrenme bağlamında yeni bir sınıf iklimi yarattığı, 67 üniversitesinin online öğrenme kurumuna dönüştüğü, bir üniversitenin açmış olduğu online EdX kursuna (www.edx.org) 120.000 kişinin kayıt olduğu belirlenmiştir.

Bununla birlikte e-öğrenme ortamlarına kayıtlı öğrenen sayısı, bu programları tamamlama konusunda garanti vermemektedir. Çünkü bu ortamlar çoğunlukla öğrenenlerin teknoloji ile kendi kendine öğrenme becerilerini esas alan ortamlar olup, öğrenme sürecinin sorumluluğu öğrencinin kendisindedir (Karaoglan Yilmaz, 2016; Yilmaz, Karaoglan Yilmaz ve Cavus Ezin, 2018). Örneğin İngiltere'de yapay zeka konusu için açılan bir eöğrenme kursuna 160.000 öğrenci kayıt olurken, yalnızca 28.000 öğrencinin programı tamamladığı (\% 17.5) belirlenmiş̧tir (Attis, Koproske ve Miller, 2012). Benzer biçimde e-öğrenmenin üniversite düzeyinde oldukça yaygın kullanıyor olmasına rağmen, çok sayıda uygulamanın da kurumsal, eğitici, öğrenen, geliştirici ve altyapıdan kaynak sorunlardan dolayı devam ettirilemediği belirlenmiştir (McGill, Klobas ve Renzi, 2014). Konuya öğrenci açısından bakıldığında cinsiyet (Akimanimpaye ve Fakude, 2015; Haznedar ve Baran, 2012; Tekinarslan, 2008), eğitim düzeyi (Keser, Karaoğlan Yılmaz ve Yılmaz, 2015), İnternete erişim durumu (Mirza, 2008; Toomhirun, 2015), akıllı telefona sahip olma durumu (Almunawar, 2015; Gerlich, Browning ve Westermann, 2010) gibi değiş̧kenlerin e-öğrenmenin etkili biçimde uygulanmasında önemli değişkenler olduğu bildirilmektedir. Bunlarla birlikte e-öğrenmedeki başarının öğrencilerin e-öğrenmeye ilişkin hazır bulunuşlukları ile de ilişkili olduğu bulunmuştur (Kaur ve Abas, 2004).

Başarılı bir e-öğrenme uygulamasının 10 temel alt boyutundan (Planlama, Hazır bulunuşluk, Yönetim, Destek, Pedagoji, Teknoloji, Fakülte, Kurum, Değerlendirme, Etik) biri olduğu bildirilen (Al-Fraihat, Joy ve Sinclair, 2017) hazır bulunuşluk, planlama aşamasından sonra, mutlaka e-öğrenme uygulaması öncesinde dikkate alınması gereken bir bileşendir. E-öğrenmeye hazır bulunuşluk; öğrenmenin niteliğini geliştirmek amacıyla öğrenenlerin e-öğrenme içerik ve materyalleri ile çokluortam araçlarından yararlanabilme yeteneği olarak tanımlanmaktadır (Kaur ve Abas, 2004). Literatür incelendiğinde e-öğrenme hazır bulunuşluğunun;

- Kural ve düzenlemeler,

- Yönetim,

- Denetim (Supervision),

- İletişim ağ 1 , 
- Kültür,

- İçerik,

- Destek,

- Değerlendirme,

- İnsan kaynakları,

- Eğitim politikas1,

- Standartlar,

- Finans,

- Güvenlik,

- Teknoloji (donanım, yazılım, sürdürülebilirlik),

- Psikolojik etmenler,

- Kurum

- Kabul,

- Hizmet-içi eğitim,

- Altyap1,

- Beceriler gibi sınıflandırıldığı görülmektedir (Al-Fraihat, Joy ve Sinclair, 2017). Bununla birlikte Yurdugül ve Demir (2017) ise e-öğrenmeye hazır bulunuşluğu; bilgisayar, internet ve çevrimiçi iletişim öz-yeterliği boyutları ile, öğrenmeye yönelik motivasyon, öğrenen kontrolü ve kendi kendine öğrenme boyutlarını içeren bir yap1 olarak ele almaktadır. Alanyazın incelendiğinde e-öğrenmeye yönelik hazır bulunuşlukla ilgili çeşitli tanımlamalara yer verildiği görülmektedir. Lopes (2007) e-öğrenmeye hazır bulunuşluğu; bir organizasyon veya bireyin çevrimiçi öğrenmenin avantajlarından yararlanabilme yeteneği olarak tanımlamaktadır. Kaur ve Abas (2004) ise; öğrenmenin niteliğini geliştirmek amacıyla öğrenenlerin e-öğrenme içerik ve materyalleri ile çokluortam araçlarından yararlanabilme yeteneği şeklinde bir tanımlama yaptığı görülmektedir. Choucri ve diğerleri (2003) ise e-öğrenmeye yönelik hazır bulunuşluğu internet gibi e-kaynakların kullanımı ile ulaşılması kolaylaşan firsatları değerlendirme yeteneği olarak tanımlamaktadır. Tanımlar genel olarak değerlendirildiğinde e-öğrenmeye yönelik hazır bulunuşluğun, e-kaynaklardan en iyi şekilde yararlanabilmek için bireylerin kendi bilgi ve becerilerinin ne ölçüde hazır olduğu ile ilgili olduğu anlaşılmaktadır. Ayrıca alanyazında çoğunlukla öğrenenlerin e-öğrenmeye ne ölçüde hazır oldukları boyutundan hazır bulunuşluğa yaklaşıldığı görülmekle birlikte, öğreticilerin ve kurumların da e-öğrenmeye yönelik hazır bulunuşluk durumuna sahip olduğu ve araştırmalarda bu iki bileşenin de hazır bulunuşluk durumunun araştırılmasının ve iyileştirmeye yönelik müdahalelerde bulunulmasının önemine dikkat çekilmektedir (Akaslan ve Law, 2011; Darab ve Montazer, 2011).

E-öğrenme uygulamalarının etkililiğinden, verimliliğinden ve çekiciliğinden bahsedebilmek için bu uygulamaların birçok unsuru dikkate alarak bütüncül bir şekilde ele alınması gerekmektedir. Bu unsurlardan; eöğrenme süreçlerinde yer alacak eğitimcilerin pedagojik ve teknik bilgi ve becerileri, öğrenenlerin bireysel farklılıklarının ve ihtiyaçlarının dikkate alınması, e-öğrenme sisteminin yönetimi, alt yapı ve teknik destek imkanları gibi başlıca unsurlar e-öğrenme uygulamalarının niteliği üzerinde belirleyici bir rol oynamaktadır. (Persico, Manca ve Pozzi, 2014; Tarhini, Hone, Liu ve Tarhini, 2017). E-öğrenme sürecinde en fazla problem yaşayan ve bunun için dışsal desteğe ihtiyaç duyan paydaşlardan biri öğrencilerdir (Yurdugül ve Demir, 2017). E-öğrenme uygulamaların başarılı biçimde devam ettirilebilmesinde öğrenenlerin katılımının sürekliliği en temel faktördür (Limayem ve Cheung, 2008; McGill, Klobas ve Renzi, 2014). Öğrenenler e-öğrenmenin onların eğitsel ihtiyaç ve beklentilerini karşılayacağını bilmeleri gerekmektedir. Öğrencilerin bireysel farklılıkları ile bu ihtiyaç ve beklentilerinin bilinmesi, kişiye özgün e-ögrenme programlarının tasarımı ve uygulanması noktasında, öğrencilere önleyici/destekleyici müdahalelerde bulunulması noktalarında oldukça önem arz etmektedir (Harman ve Çelikler, 2012). Bu noktada e-öğrenme sürecine henüz başlanmadan, öğrencilerin e-öğrenmeye hazır bulunuşluklarını belirlemek e-öğrenme sürecinin etkiliği, verimliliği ve çekiciliğine olumlu yansıyacaktır.

Alanyazın incelendiğinde üniversite öğrencilerinin e-öğrenmeye yönelik hazır bulunuşluklarını incelemeye yönelik araştırmaların çoğunlukla eğitim fakültesi gibi belirli bir fakültede/yüksekokulda öğrenim gören öğrenciler üzerinde yapıldığı görülmektedir. Ancak araştırma sonuçlarının genellenebilirliğinin sağlanabilmesi ve fakülteler/yüksekokullar bazında karşılaştırma yaparak, birim bazında öğrencilerin e-öğrenmeye yönelik hazır bulunuşluk durumlarının tespit edilebilmesi, karşılaştırmalar yapılabilmesi, birim bazlı ihtiyaç analizi raporlarının hazırlanabilmesi mümkündür. Böylece birim bazlı ihtiyaç analizi ortaya konularak bu ihtiyacın 
giderilmesine yönelik birimlerin öğretim programlarında güncellemeler yapabilmek, birim bazlı kurumsal alt yapıyı geliştirmeye yönelik önlemler alabilmek mümkün olacaktır. $\mathrm{Bu}$ nedenle bu araştırma ile fakülteler/yüksekokul bazında karşılaştırmalar yapması açısından alanyazına katkı sağlamaya çalışılmıştır. Sınıf düzeyinde (birinci ve son sınıf karşılaşıırması) karşılaştırmalar yapılarak da birimlerin öğretim programlarının öğrencileri e-öğrenmeye hazır hale getirmede ne ölçüde işlev gördüğünü tespit edebilmek de mümkün olacaktır. Bu nedenle bu araştırmada sınıf düzeyinde karşılaştırmalara da yer verilmiştir. Bireylerin e-öğrenmeye yönelik hazır bulunuşlukları üzerinde bireysel farklılıkların etkili olup olmadığını belirlemek önemlidir. Bireysel farklılıklara göre öğrencilerin e-öğrenmeye hazır bulunuşluklarını artırmaya yönelik önlemler alabilmek önemlidir. Bireylerin sahip oldukları bilişim teknolojisi araçları ile ilgili olanaklar öğrencilerin hazır bulunuşlukları üzerinde anlamlı bir farklılığa yol açabileceği düşünülmektedir. Ancak alanyazın incelendiğinde bu araştırılması gereken bir varsayım olarak karşımıza çıkmaktadır. Bu bağlamda, araştırma kapsamında öğrencilerin sahip olduğu kişisel bilgisayar ve internet bağlantısı olan akıllı telefon olanaklarının e-öğrenmeye hazır bulunuşluk üzerinde anlamlı bir fark oluşturup oluşturmadığı araştırılmıştır. Araştırma kapsamında incelenen bireysel farklılıklardan bir diğeri de cinsiyet değişkenidir. Alanyazın incelendiğinde cinsiyet değişkeninin bireylerin teknoloji ile ilgili davranış, inanış ve tutumları üzerinde etkili olabildiği ifade edilmektedir (Karaoğlan Yılmaz ve Kılıç Çakmak, 2016). Cinsiyetin e-öğrenme hazır bulunuşluğu üzerinde anlamlı bir farklılığa yol açıp açmayacağı ise merak edilen bir diğer noktadır. Bu doğrultuda gerçekleştirilen bu araştırmanın amacı üniversite öğrencilerinin e-öğrenmeye hazır bulunuşluk düzeylerini belirlemek ve bunu çeşitli değişkenlere göre incelemektir. Bu amaç doğrultusunda aşağıdaki sorulara yanıt aranmıştır.

1) Bartın Üniversitesi öğrencilerinin e-öğrenmeye hazır bulunuşluk düzeyleri nedir?

2) Bartın Üniversitesi öğrencilerinin e-öğrenmeye hazır bulunuşlukları sırasıyla;

a) Cinsiyete,

b) Sinıf düzeyine,

c) Kişisel bilgisayara sahip olma durumuna,

d) Internet bağlantısı olan akıllı telefona sahip olma durumuna,

e) Öğrenim görülen fakülte/yüksekokula göre manidar farklılık göstermekte midir?

\section{Yöntem}

\section{Araștırmanın Modeli}

$\mathrm{Bu}$ çalışmada üniversite öğrencilerinin e-öğrenmeye hazır bulunuşluklarını incelemek ve bunun üzerinde ilgili olan değiş̧enleri tespit etmek için tarama modelinden yararlanılmıştır. Bu model bir vaka ya da durumu mevcut yapısıyla ortaya koymayı hedefleyen modellerdir (Creswell, 2009). Bu araştırmada da üniversite öğrencilerinin e-öğrenmeye hazır bulunuşluk düzeyleri ve bunun üzerinde etkili olan değişkenler tarama modeliyle belirlenmeye çalışılmıştır.

\section{Evren ve Örneklem}

Araştırmanın katılımcılarını Bartın Üniversitesinde birinci ve son sınıfta öğrenim gören öğrenciler oluşturmaktadır. $\mathrm{Bu}$ doğrultuda araştırmaya fakülte ve yüksekokulların birinci ve dördüncü sınıf öğrencileri katılırken, meslek yüksekokullarında ise birinci ve ikinci sınıftaki öğrenciler katılmıştır. Bu bağlamda araştırma verileri lisans ve önlisans düzeyinde araştırmaya gönüllü olarak katılarak 5021 öğrenciden elde edilmiştir. Öğrencilere ilişkin demografik bilgiler Tablo 1'de verilmiştir.

Tablo 1

Katılımcılara İlişkin Demografik Veriler

\begin{tabular}{lccc}
\hline Değişken & Grup & $N$ & $\%$ \\
\hline \multirow{2}{*}{ Cinsiyet } & Kadın & 2685 & 53.4 \\
& Erkek & 2336 & 46.6 \\
Sınıf Düzeyi & Birinci Sınıf & 2348 & 46.8 \\
& Son Sınıf & 2673 & 53.2 \\
Kişisel bilgisayara sahip olma durumu & Var & 3876 & 77.2 \\
(masaüstü, dizüstü, tablet pc) & Yok & 1145 & 22.8 \\
İnternet bağlantısı olan akıllı telefona sahip & Var & 4895 & 97.5 \\
olma durumu & Yok & 126 & 2.5 \\
& & & \\
\hline
\end{tabular}


Tablo $1-$ Devam

\begin{tabular}{|c|c|c|c|}
\hline Değișken & Grup & $N$ & $\%$ \\
\hline \multirow{10}{*}{ Fakülteler / Yüksekokullar } & İktisadi ve İdari Bilimler Fakültesi & 994 & 19.8 \\
\hline & Edebiyat Fakültesi & 838 & 16.69 \\
\hline & Eğitim Fakültesi & 621 & 12.37 \\
\hline & Beden Eğitimi ve Spor Yüksekokulu & 605 & 12.05 \\
\hline & Meslek Yüksekokulu & 576 & 11.47 \\
\hline & Sağlık Hizmetleri Meslek Yüksekokulu & 448 & 8.92 \\
\hline & Mühendislik Fakültesi & 447 & 8.9 \\
\hline & İslami İlimler Fakültesi & 276 & 5.50 \\
\hline & Fen Fakültesi & 152 & 3.02 \\
\hline & Orman Fakültesi & 64 & 1.27 \\
\hline
\end{tabular}

Tablo 1 incelendiğinde araștırmaya katılan öğrencilerin cinsiyete göre dağılımlarının yaklaşık olarak eșit olduğu görülmektedir. Benzer şekilde öğrencilerin sınıf düzeyine göre dağılımlarının (birinci ve son sınıfta olma durumuna göre) da yaklaşık olarak eşit olduğu tespit edilmiştir. Öğrencilerin öğrenimlerinin ilk ve son yıllarında seçilmelerinin bir gerekçesi, verilen eğitimin hazır bulunuşluklarına bir etkisinin olup olmadığının belirlenmesidir. Öğrenim görülen birime göre araştırmaya katılan öğrencilerin dağılımları incelendiğinde Fen Fakültesi, İslami İlimler Fakültesi ve Orman Fakültesinden katılımın diğer birimlere göre daha az olduğu görülmektedir. Bunun nedeni ise diğer birimlerde öğrenim gören öğrencilere kıyasla bu birimlerde öğrenim gören öğrenci sayısının daha az olmasıdır. Diğer birimlerden araştırmaya katılan öğrencilerin sayısının ise yaklaşık olarak birbirine eşit olduğu söylenebilir. Tablo 1'den elde edilen bir diğer bulguya göre yaklaşık her üç öğrenciden birinin kişisel bilgisayara (masaüstü, dizüstü, tablet pc) sahip olduğu görülürken, hemen hemen her öğrencinin İnternet bağlantısı olan akıllı telefona sahip olduğu anlaşılmaktadır. Bu doğrultuda mobil öğrenmenin günümüz öğrencileri için önemli olduğu ifade edilebilir.

\section{Veri Toplama Araçları}

Bu araştırmanın verileri; demografik bilgiler formu ve üniversite öğrencilerinin e-öğrenmeye hazır bulunuşluğu ölçeği kullanılarak elde edilmiştir.

Demografik Bilgiler Formu. Demografik bilgiler formu ile araştırmaya katılan öğrencilerin öğrenim görülen bölüm, fakülte, yaş, cinsiyet, öğrenim görülen sınıf düzeyi gibi kişisel bilgileri tespit edilmeye çalışılmıştır.

E-Öğrenmeye Hazır Bulunuşluk Ölçeği. Ölçek, öğrencilerin e-öğrenmeye hazır bulunuşluk durumlarını belirlemek amacıyla Yurdugül ve Demir (2017) tarafından geliştirilmiştir. Ölçek 6 faktör ve toplamda 33 maddeden oluşmaktadır. Ölçek 'Bana Hiç Uygun Değil' (1) ile 'Bana Tamamen Uygun' (7) arasında değişecek şekilde 7'li likert derecelendirmeye sahiptir. Bu çalışma için yeniden hesaplanan ölçek faktörlerinin Cronbach Alfa güvenirlik değerleri .80 ile .92 arasında değişmekte olup, ölçeğin geneli için güvenirlik değeri .94 olarak belirlenmiştir. Ölçekten alınan puanın yüksek olması öğrencilerin e-öğrenmeye hazır bulunuşluklarının yüksek olduğunu göstermektedir. Çalışma kapsamında uygulanan DFA sonucunda elde edilen bazı uyum iyiliği indisleri raporlanmıştır. $\mathrm{Bu}$ uyum iyiliği indisleri; RMSEA .07, NFI .98, NNFI .98, IFI .96 ve CFI .98 olarak belirlenmiştir.

\section{Veri Toplama Süreci}

Veri toplama araçlarına nihai şekli verildikten sonra veri toplama araçları optik form şeklinde çoğaltılarak öğrenciye uygulanmıştır. Söz konusu optik formlar Bartın Üniversitesinin tüm birimlerinde öğrenim gören ve araştırmaya katılmaya istekli öğrencilere uygulanmıştır. Araştırma verileri 2016-2017 akademik yılı süresince toplanmış olup, optik formlar optik okuyucuda okutularak veriler elektronik ortama aktarılmıştır.

\section{Veri Analizi}

Analiz sürecinde yüzde, ortalama, frekans ve standart sapma gibi betimsel istatistikler kullanılmıștır. Bununla birlikte verilerin normallik ve homojenlik gibi varsayımları sağlayıp sağlamadıkları kontrol etmek için çarpıklık ve basıklık değerleri kullanılmıştır. Verilerin normal dağılmadığı durumlarda Mann-Whitney U ve Kruskal Wallis Testi yapılmıştır. Araştırmada .05 anlamlılık seviyesi olarak esas alınmıştır. 


\section{Bulgular}

Araştırma kapsamında üniversite öğrencilerinin e-öğrenmeye hazır bulunuşlukları ne düzeydedir sorusuna yanıt aranmıştır. Tablo 2'de üniversite öğrencilerinin e-öğrenmeye hazır bulunuşluk ölçeği geneli ve faktörlerinden aldıkları puanlara ilişkin bulgular gösterilmektedir.

Tablo 2

Üniversite Öğrencilerinin E-öğrenmeye Hazır Bulunuşluğa İlişkin Betimsel İstatistikler

\begin{tabular}{lcccccc}
\hline Ölçekler & $\begin{array}{c}\text { Madde } \\
\text { sayıs1 }\end{array}$ & $\begin{array}{c}\text { En düşük } \\
\text { puan }\end{array}$ & $\begin{array}{c}\text { En } \\
\text { yüksek } \\
\text { puan }\end{array}$ & $\bar{X}$ & ss & $\bar{X} / k$ \\
\hline E-Öğrenmeye Hazır Bulunuşluk Ölçeği & 33 & 33 & 231 & 171.77 & 42.83 & 5.20 \\
Bilgisayar öz-yeterliği (Alt faktör 1) & 5 & 5 & 35 & 24.50 & 7.86 & 4.90 \\
İnternet öz-yeterliği (Alt faktör 2) & 4 & 4 & 28 & 23.12 & 5.82 & 5.78 \\
Çevrimiçi iletişim öz yeterliliği (Alt faktör 3) & 5 & 5 & 35 & 26.27 & 7.61 & 5.25 \\
Kendi kendine öğrenme (Alt faktör 4) & 8 & 8 & 56 & 42.32 & 11.36 & 5.29 \\
Öğgrenen kontrolü (Alt faktör 5) & 4 & 4 & 28 & 21.43 & 6.04 & 5.35 \\
E-öğrenmeye yönelik motivasyon (Alt faktör 6) & 7 & 7 & 49 & 34.11 & 11.47 & 4.87 \\
\hline
\end{tabular}

Tablo 2'deki bulgular incelendiğinde öğrencilerin e-öğrenmeye yönelik hazır bulunuşluk ölçeği genelinden aldıkları en düşük puanın 33, en yüksek puanın 231, ölçek ortalamasının ise 171.77 olduğu görülmektedir. $\bar{X} / \mathrm{k}$ değeri dikkate alındığında ölçek geneli için öğrencilerin hazır bulunuşluk düzeylerinin yüksek olduğu söylenebilir. Tablo 2 incelendiğinde, öğrencilerin bilgisayar öz-yeterliklerinin ve e-öğrenmeye yönelik motivasyonlarının orta düzeyde olduğu söylenebilir. Diğer taraftan öğrencilerin İnternet öz-yeterliklerinin, çevrimiçi iletişim öz-yeterliklerinin, kendi kendine öğrenme yeterliliklerinin yüksek düzeyde olduğu söylenebilir. Öğrencilerin öğrenen kontrolü alt faktörüne ilişkin düzeylerinin de yüksek düzeyde olduğu söylenebilir. Bu bulgular 1şı̆̆ında, öğrencileri e-öğrenme sürecine hazırlamada öncelikle onların bilgisayar bilgi ve becerilerini geliştirmenin, bu konudaki yetkinliklerini artırarak, öz-yeterliklerini geliştirmenin önemli olduğu söylenebilir. Yine, e-öğrenme sürecine başlanmadan önce öğrencilerin motivasyonlarını geliştirmeye yönelik önlemlerin alınması önemlidir.

\section{Cinsiyet}

Araştırma kapsamında, cinsiyete göre öğrencilerin e-öğrenme hazır bulunuşluklarına ilişkin sonuçlar Tablo 3'de sunulmuştur.

Tablo 3

Üniversite Öğrencilerinin E-öğrenmeye Hazır Bulunuşluk Düzeylerinin Cinsiyete Göre Betimsel İstatistikleri ve Mann Whitney U Testi Sonuçlart

\begin{tabular}{lcccccccc} 
Ölçek & Cinsiyet & $N$ & $\bar{X}$ & $S S$ & Sira Ortalaması & Siralar Toplamı & $U$ & $P$ \\
\hline \multirow{2}{*}{ Bilgisayar öz-yeterliği } & Kadın & 2685 & 23.62 & 7.82 & 2340.61 & 6284540.00 & 2678585 & .000 \\
& Erkek & 2336 & 25.51 & 7.80 & 2706.85 & 6323191.00 & & \\
İnternet öz-yeterliği & Kadın & 2685 & 22.78 & 6.11 & 2435.61 & 6539615.50 & 2933660.5 & .000 \\
& Erkek & 2336 & 23.52 & 5.46 & 2597.65 & 6068115.50 & & \\
Çevrimiçi iletişim öz & Kadın & 2685 & 25.41 & 7.99 & 2360.80 & 6338748.50 & \multirow{2}{*}{2732793.5} & .000 \\
yeterliliği & Erkek & 2336 & 27.26 & 7.04 & 2683.64 & 6268982.50 & & \\
& Kadın & 2685 & 41.60 & 11.85 & 2435.41 & 6539088.00 & 2933133 & .000 \\
Kendi kendine öğrenme & Erkek & 2336 & 43.15 & 10.72 & 2597.88 & 6068643.00 & & \\
& Kadın & 2685 & 21.01 & 6.34 & 2427.19 & 6517016.50 & 2911061.5 & .000 \\
Öğrenen kontrolü & Erkek & 2336 & 21.93 & 5.64 & 2607.33 & 6090714.50 & & \\
\multirow{2}{*}{$\begin{array}{l}\text { E-öğrenmeye yönelik } \\
\text { motivasyon }\end{array}$} & Kadın & 2685 & 32.83 & 11.69 & 2349.47 & 6308319.50 & 2702364.5 & .000 \\
Ëlçek Geneli & Erkek & 2336 & 35.60 & 11.05 & 2696.67 & 6299411.50 & & \\
& Kadın & 2685 & 167.25 & 44.2 & 2363.71 & 6346561.50 & 2740606.5 & .000 \\
& Erkek & 2336 & 176.97 & 40.48 & 2680.30 & 6261169.50 & & \\
\hline
\end{tabular}


Tablo 3 incelendiğinde, kadın öğrencilerin e-öğrenmeye hazır bulunuşluk ölçeği geneli için puan ortalaması 167.25 iken, erkek öğrencilerin puan ortalaması 176.97'dir. Cinsiyet değişkenine göre ölçekten elde edilen puan ortalamaları arasında farklılıkların ortaya çıktığı tespit edilmiştir. Bu durumun manidar olup olmadığı Mann Whitney U testi kullanılarak incelenmiştir. Testin sonuçları ölçeğin geneli ve alt faktörleri için bu farklılığın anlamlı olduğunu göstermektedir. Bu bulguya göre kadın öğrencilerin ölçek geneli ve her bir alt faktörü için eöğrenme hazır bulunuşluklarının erkek öğrencilere göre daha düşük olduğu söylenebilir.

\section{Sinıf Düzeyi}

Araştırma kapsamında, sınıf düzeyine göre öğrencilerin e-öğrenme hazır bulunuşluklarına ilişkin sonuçlar Tablo 4'de sunulmuştur.

Tablo 4

Üniversite Öğrencilerinin E-öğrenmeye Hazır Bulunuşluk Düzeylerinin Sinıf Düzeyine Göre Betimsel İstatistikleri ve Mann Whitney U Testi Sonuçları

\begin{tabular}{|c|c|c|c|c|c|c|c|c|}
\hline Ölçek & Sinıf Düzeyi & $N$ & $X$ & $S S$ & Sira Ortalamas1 & Siralar Toplamı & $U$ & $P$ \\
\hline Bilgisayar öz-yeterliği & $\begin{array}{l}\text { Birinci Sinif } \\
\text { Son Sinif }\end{array}$ & $\begin{array}{l}2348 \\
2673\end{array}$ & $\begin{array}{l}23.79 \\
25.12\end{array}$ & $\begin{array}{l}7.89 \\
7.79\end{array}$ & $\begin{array}{l}2373.95 \\
2631.38\end{array}$ & $\begin{array}{l}5574043.5 \\
7033687.5\end{array}$ & 2816317.5 & .000 \\
\hline İnternet öz-yeterliği & $\begin{array}{l}\text { Birinci Sinif } \\
\text { Son Sinif }\end{array}$ & $\begin{array}{l}2348 \\
2673\end{array}$ & $\begin{array}{l}22.66 \\
23.53\end{array}$ & $\begin{array}{l}5.94 \\
5.69\end{array}$ & $\begin{array}{l}2621.58 \\
2385.10\end{array}$ & $\begin{array}{l}5600225 \\
7007506\end{array}$ & 2842499 & .000 \\
\hline $\begin{array}{l}\text { Çevrimiçi iletişim öz } \\
\text { yeterliliği }\end{array}$ & $\begin{array}{l}\text { Birinci Sinif } \\
\text { Son Sinif }\end{array}$ & $\begin{array}{l}2348 \\
2673\end{array}$ & $\begin{array}{l}25.79 \\
26.69\end{array}$ & $\begin{array}{l}7.71 \\
7.51\end{array}$ & $\begin{array}{l}2415.49 \\
2594.88\end{array}$ & $\begin{array}{l}5671592.5 \\
6936138.5\end{array}$ & 2913866.5 & .000 \\
\hline Kendi kendine öğrenme & $\begin{array}{l}\text { Birinci Sinıf } \\
\text { Son Sinif }\end{array}$ & $\begin{array}{l}2348 \\
2673\end{array}$ & $\begin{array}{l}41.27 \\
43.23\end{array}$ & $\begin{array}{l}11.71 \\
10.97\end{array}$ & $\begin{array}{l}2381.78 \\
2624.50\end{array}$ & $\begin{array}{l}5592436.5 \\
7015294.5\end{array}$ & 2834710.5 & .000 \\
\hline Öğrenen kontrolü & $\begin{array}{l}\text { Birinci Sinif } \\
\text { Son Sinif }\end{array}$ & $\begin{array}{l}2348 \\
2673\end{array}$ & $\begin{array}{l}20.86 \\
21.93\end{array}$ & $\begin{array}{l}6.20 \\
5.85\end{array}$ & $\begin{array}{l}2370.87 \\
2634.08\end{array}$ & $\begin{array}{l}5566809.5 \\
7040921.5\end{array}$ & 2809083.5 & .000 \\
\hline $\begin{array}{l}\text { E-öğrenmeye yönelik } \\
\text { motivasyon }\end{array}$ & $\begin{array}{l}\text { Birinci Sinıf } \\
\text { Son Sinıf }\end{array}$ & $\begin{array}{l}2348 \\
2673\end{array}$ & $\begin{array}{l}32.84 \\
35.23\end{array}$ & $\begin{array}{l}11.92 \\
10.95\end{array}$ & $\begin{array}{l}2360.57 \\
2643.13\end{array}$ & $\begin{array}{c}5542638 \\
7065092.9\end{array}$ & 2784912 & .000 \\
\hline Ölçek Geneli & $\begin{array}{l}\text { Birinci Sinif } \\
\text { Son Sinıf }\end{array}$ & $\begin{array}{l}2348 \\
2673\end{array}$ & $\begin{array}{l}167.24 \\
175.75\end{array}$ & $\begin{array}{l}43.90 \\
41.47\end{array}$ & $\begin{array}{l}2355.96 \\
2647.18\end{array}$ & $\begin{array}{l}5531806.5 \\
7075924.5\end{array}$ & 2774080.5 & .000 \\
\hline
\end{tabular}

Tablo 4 incelendiğinde, birinci sınıftaki öğrencilerin e-öğrenmeye hazır bulunuşluk ölçeği geneli puan ortalaması 167.24 iken, son sınıftaki öğrencilerin puan ortalaması $175.75^{\prime}$ dir. Sınıf düzeyi değişkenine göre ölçekten elde edilen puan ortalamaları arasında farklılıkların ortaya çıktığı tespit edilmiştir. Bu durumun manidar olup olmadığı Mann Whitney U testi kullanılarak incelenmiştir. Testin sonuçları ölçeğin geneli ve alt faktörleri için bu farklılığın anlamlı olduğunu göstermektedir. Bu bulguya göre birinci sınıftaki öğrencilerin ölçek geneli ve her bir alt faktörü için e-öğrenme hazır bulunuşluklarının son sınıftaki öğrencilere göre daha düşük olduğu söylenebilir.

\section{Kișisel Bilgisayara Sahip Olma Durumu}

Araştırma kapsamında, kişisel bilgisayara sahip olma durumuna göre öğrencilerin e-öğrenme hazır bulunuşluklarına ilişkin sonuçlar Tablo 5'de sunulmuştur.

Tablo 5

Üniversite Ö̆ğrencilerinin E-öğrenmeye Hazır Bulunuşluk Düzeylerinin Kişisel Bilgisayara Sahip Olma Durumuna Göre Betimsel İstatistikleri ve Mann Whitney U Testi Sonuçları

\begin{tabular}{lcccccccc}
\hline Ölçek & $\begin{array}{c}\text { Kişisel } \\
\text { Bilgisayara sahip } \\
\text { Olma Durumu }\end{array}$ & $N$ & $X$ & $S S$ & $\begin{array}{c}\text { Sira } \\
\text { Ortalaması }\end{array}$ & Siralar Toplamı & $U$ & $P$ \\
\hline \multirow{2}{*}{ Bilgisayar öz-yeterliği } & Var & 3876 & 25.54 & 7.47 & 2697.95 & 10457291 & 1494355 & .000 \\
& Yok & 1145 & 20.95 & 8.10 & 1878.11 & 2150440 & & \\
İnternet öz-yeterliği & Var & 3876 & 23.68 & 5.50 & 2649.42 & 10269184.5 & 1682461.5 & .000 \\
& Yok & 1145 & 21.23 & 6.47 & 2042.39 & 2338546.5 & & \\
Çevrimiçi iletişim öz & Var & 3876 & 27.09 & 7.22 & 2659.81 & 10309431.5 & 1642214.5 & .000 \\
yeterliliği & Yok & 1145 & 23.50 & 8.23 & 2007.24 & 2298299.5 & & \\
\multirow{2}{*}{ Kendi kendine öğrenme } & Var & 3876 & 43.38 & 10.77 & 2637.3 & 10222210 & 1729436 & .000 \\
& Yok & 1145 & 38.70 & 12.51 & 2083.42 & 2385521 & & \\
\hline
\end{tabular}


Tablo 5 -Devam

\begin{tabular}{llcccccccc}
\hline \multirow{2}{*}{ Ölçek } & $\begin{array}{l}\text { Kişisel } \\
\text { Bilgisayara sahip }\end{array}$ & $N$ & $X$ & $S S$ & Sira Ortalaması & $\begin{array}{c}\text { Siralar } \\
\text { Toplamı }\end{array}$ & $U$ & $P$ \\
& Olma Durumu & & & & & & \\
& Var & 3876 & 21.93 & 5.78 & 2623.29 & 10167901.5 & 1783744.5 & .000 \\
Öğrenen kontrolü & Yok & 1145 & 19.75 & 6.57 & 2130.85 & 2439829.5 & & \\
& Var & 3876 & 34.86 & 11.25 & 2603.17 & 10089894 & 1861752 & .000 \\
E-öğrenmeye yönelik & Yok & 1145 & 31.59 & 11.85 & 2198.98 & 2517837 & & \\
motivasyon & Var & 3876 & 176.50 & 40.52 & 2663.26 & 10322804.5 & 1628841.5 & .000 \\
Ölçek Geneli & Yok & 1145 & 155.74 & 46.41 & 1995.56 & 2284926.5 & & \\
\hline
\end{tabular}

Tablo 5 incelendiğinde, kişisel bilgisayara (masaüstü, dizüstü ya da tablet) sahip olan öğrencilerin e-öğrenmeye hazır bulunuşluk ölçeği geneli puan ortalaması 176.50 iken, kişisel bilgisayara sahip olmayan öğrencilerin puan ortalaması 155.74 'dir. Kişisel bilgisayara sahip olma değişkenine göre ölçekten elde edilen puan ortalamaları arasında farklılıkların ortaya çıktığı tespit edilmiştir. Bu durumun manidar olup olmadığı Mann Whitney U testi kullanılarak incelenmiştir. Testin sonuçları ölçeğin geneli ve alt faktörleri için bu farklılığın anlamlı olduğunu göstermektedir. Bu bulguya göre kişisel bilgisayara sahip olan öğrencilerin ölçek geneli ve her bir alt faktörü için e-öğrenme hazır bulunuşluklarının daha yüksek olduğu söylenebilir.

\section{Akıllı Telefona Sahip Olma Durumu}

Araştırma kapsamında, internet bağlantısı olan akıllı telefona sahip olma durumuna göre öğrencilerin e-öğrenme hazır bulunuşluklarına ilişkin sonuçlar Tablo 6'da sunulmuştur.

Tablo 6

Üniversite Öğrencilerinin E-öğrenmeye Hazır Bulunuşluk Düzeylerinin İnternet Bağlantısı Olan Akıllı Telefona Sahip Olma Durumuna Göre Betimsel İstatistikleri ve Mann Whitney U Testi Sonuçları

\begin{tabular}{lcccccccc}
\hline Ölçek & $\begin{array}{c}\text { Kişisel Bilgisayara } \\
\text { sahip Olma } \\
\text { Durumu }\end{array}$ & $N$ & $X$ & $S S$ & $\begin{array}{c}\text { Sira } \\
\text { Ortalamas1 }\end{array}$ & $\begin{array}{c}\text { Siralar } \\
\text { Toplamı }\end{array}$ & $U$ & $P$ \\
& Var & 4895 & 24.65 & 7.79 & 2537.53 & 124212145 & 178515.5 & .000 \\
Bilgisayar öz-yeterliği & Yok & 126 & 18.32 & 8.21 & 1480.28 & 186516.5 & \\
& Var & 4895 & 23.23 & 5.76 & 2535.54 & 12411472 & 188258 & .000 \\
İnternet öz-yeterliği & Yok & 126 & 18.92 & 6.83 & 1557.61 & 196259 & & \\
& Var & 4895 & 26.36 & 7.58 & 2529.44 & 12381627 & 218103 & .000 \\
Çevrimiçi iletişim öz & Yok & 126 & 22.5 & 7.97 & 1794.47 & 226104 & & \\
yeterliliği & Var & 4895 & 42.41 & 11.34 & 2523.18 & 12350979 & 248751 & .000 \\
Kendi kendine öğrenme & Yok & 126 & 38.81 & 11.58 & 2037.71 & 256752 & & \\
& Var & 4895 & 21.49 & 6.02 & 2524.25 & 12356236 & 243494 & .000 \\
Öğrenen kontrolü & Yok & 126 & 19.36 & 6.28 & 1995.99 & 251495 & & \\
E-öğrenmeye yönelik & Var & 4895 & 34.18 & 11.48 & 2520.33 & 123370305 & 262699.5 & .000 \\
motivasyon & Yok & 126 & 31.45 & 10.90 & 2148.41 & 270700.5 & & \\
& Var & 4895 & 172.35 & 42.69 & 2531.13 & 12389898 & 209832 & .000 \\
Ölçek Geneli & Yok & 126 & 149.38 & 42.55 & 1728.83 & 217833 & \\
\hline
\end{tabular}

Tablo 6 incelendiğinde, internet bağlantısı olan akıllı telefona sahip olan öğrencilerin e-öğrenmeye hazır bulunuşluk ölçeği geneli puan ortalaması 172.35 iken, sahip olmayan öğrencilerin puan ortalaması 149.38 'dir. İnternet bağlantısı olan akıllı telefona sahip olma değişkenine göre ölçekten elde edilen puan ortalamaları arasında farklılıkların ortaya çıktığı tespit edilmiştir. Bu durumun manidar olup olmadığı Mann Whitney U testi kullanılarak incelenmiştir. Testin sonuçları ölçeğin geneli ve alt faktörleri için bu farklılığın anlamlı olduğunu göstermektedir. Bu bulguya göre internet bağlantısı olan akıllı telefona sahip olan öğrencilerin ölçek geneli ve her bir alt faktörü için e-öğrenme hazır bulunuşluklarının daha yüksek olduğu söylenebilir.

\section{Öğrenim Görülen Fakülte/Yüksekokul}

Araştırma kapsamında, öğrenim görülen fakülteye/yüksekokula göre öğrencilerin e-öğrenme hazır bulunuşluklarına ilişkin sonuçlar Tablo 7'de sunulmuştur. 
Tablo 7

Üniversite Öğrencilerinin E-öğrenmeye Hazır Bulunuşluk Düzeylerinin Öğrenim Görülen Fakülteye/Yüksekokula Göre Betimsel İstatistikleri ve Kruskal Wallis Testi Sonuçları

\begin{tabular}{|c|c|c|c|c|c|c|c|}
\hline Fakülte/Yüksekokul & $N$ & $\bar{X}$ & ss & $\begin{array}{l}\text { Sira } \\
\text { Ortalamas1 }\end{array}$ & $d f$ & $X^{2}$ & $p$ \\
\hline Edebiyat Fakültesi & 838 & 172.36 & 40.74 & 2504.72 & \multirow{10}{*}{9} & \multirow{10}{*}{67.798} & \multirow{10}{*}{.000} \\
\hline Eğitim Fakültesi & 621 & 173.89 & 37.84 & 2535.20 & & & \\
\hline Fen Fakültesi & 152 & 182.30 & 43.23 & 2953.89 & & & \\
\hline İktisadi ve İdari Bilimler Fakültesi & 994 & 174.49 & 42.11 & 2607.87 & & & \\
\hline İslami İlimler Fakültesi & 276 & 156.22 & 50.00 & 2080.25 & & & \\
\hline Mühendislik Fakültesi & 447 & 171.60 & 43.47 & 2509.52 & & & \\
\hline Orman Fakültesi & 64 & 177.12 & 43.01 & 2691.46 & & & \\
\hline Beden Eğitimi ve Spor Yüksekokulu & 605 & 170.53 & 38.36 & 2403.70 & & & \\
\hline Meslek Yüksekokulu & 576 & 175.11 & 47.28 & 2690.47 & & & \\
\hline Sağlık Hizmetleri Meslek Yüksekokulu & 448 & 164.5 & 45.87 & 2279.16 & & & \\
\hline
\end{tabular}

Tablo 7 incelendiğinde, öğrencilerin öğrenim gördükleri fakülteye/yüksekokula göre e-öğrenmeye hazır bulunuşluk ölçeği ortalamalarının değişkenlik gösterdiği görülmektedir. Bu farklılığın manidar olup olmadığı Kruskal Wallis Testi kullanılarak incelenmiştir. Test sonuçları incelendiğinde göre e-öğrenmeye hazır bulunuşluk puan ortalaması en düşük olan fakültenin İslami İlimler Fakültesi $(\bar{x}=156.22)$ olduğu görülürken, en yüksek olan fakültenin ise Fen Fakültesi $(\bar{X}=156.22)$ olduğu görülmüştür. Üniversite genel ortalaması ise ölçek ortalamasının ise $(\bar{X}=171.77)$ 'dir. Buna göre fakülte/yüksekokul öğrencileri arasında e-öğrenmeye hazır bulunuşluk açısından farklılıklar anlamlı bulunmaktadır. Gruplar arasında manidar farklılığın hangi gruplar arasında olduğu incelendiğinde bu farkın İslami İlimler Fakültesi ile Fen Fakültesi, Sağlık Hizmetleri Meslek Yüksekokulu ile Fen Fakültesi arasında olduğu görülmektedir.

\section{Sonuç ve Tartışma}

Eğitim ve öğretim uygulamalarında hızla artan e-öğrenme uygulamalarının başarılı biçimde gerçekleşebilmesinde öğrencilerin hazır bulunuşlukları önemli görülmektedir (Kaymak ve Horzum, 2013; Pannen ve Abubakar, 2005). Hazır bulunuşluğun öğrenme deneyimi memnuniyeti (Yılmaz, 2017), öz-yönelim, öğrenme ortamıyla etkileşim (Kaymak ve Horzum, 2013), akademik başarı (Kaur ve Abas 2004) gibi birçok değişken üzerinde etkili olduğu belirlenmiştir. Öğrencilerin bu hazır bulunuşluğa sahip olabilmelerinin ön koşulu ise gerekli ve yeterli olan teknolojiye sahip olmaları ve BİT kullanım alışkınlığı kazanmış olmalarıdır. Nitekim bunu doğrular nitelikte araştırmanın alt probleminde ele alınan kişisel bilgisayara ve akıllı telefona sahip olan öğrencilerin e-öğrenmeye hazır bulunuşluk durumlarının anlamlı derecede yüksek olduğu görülmüştür. Bu nedenle e-öğrenmeye geçiş sürecinde öğrencilerin teknolojiye sahip olma durumları ile ilgili ihtiyaç analizi çalışmalarının yapılması bu sürecin başarılı olması için önemlidir. Gerekli donanıma sahip olmayan öğrenciler için üniversiteler internete erişebilmelerine olanak sağlayacak gerekli donanımı temin etmelidirler. Asaari, Hasmi ve Karia'nın (2005) da dediği gibi; donanım, öğrencilerin e-öğrenmeye hazır olması için bir ön koşuldur. Alanyazın incelendiğinde teknolojik erişim yetersizliği, teknolojik alt yapı yetersizliği, teknoloji kullanımı ile ilgili eğitim yetersizliği, teknik destek yetersizliği gibi problemlerin öğrencilerin e-öğrenme hazır bulunuşluğunu olumsuz etkilediği belirtilmiştir (Esterhuyse ve Scholtz, 2015; Islam, Beer ve Slack, 2015; Mulugeta ve Buckley, 2015; Nawaz ve Qureshi, 2010; Naresh ve Reddy, 2015). Bu nedenle eğitim kurumları öğrencilerin e-öğrenme hazır bulunuşluklarına katkı sağlayabilmek için bilgisayar gibi teknolojik araç olanakları olmayan öğrencilerin kullanımına yönelik bilgisayar sınıfları gibi ortamlar oluşturarak, öğrencilerin teknolojik erişim problemlerinin çözümüne olanak sunabilmelidir.

Araştırmanın birinci alt problemine ilişkin sonuçlar incelendiğinde öğrencilerin e-öğrenmeye yönelik hazır bulunuşluk düzeylerinin yüksek düzeyde olduğu görülmektedir. Alt boyutlar açısından öğrencilerin hazır bulunuşluğu incelendiğinde yüksekten düşüğe doğru sırasıyla; İnternet öz-yeterliği, öğrenen kontrolü, kendi kendine öğrenme, çevrimiçi iletişim öz yeterliği, bilgisayar öz-yeterliği ve e-öğrenmeye yönelik motivasyon olarak belirlenmiştir. Alt boyutlar açısından bakıldığında bilgisayar öz-yeterliği ve e-öğrenmeye yönelik motivasyon alt boyutlarının orta düzeyde olduğu görülürken; internet öz-yeterliği, çevrimiçi iletişim öz-yeterliği, kendi kendine öğrenme ve öğrenen kontrolü alt boyutlarının ise yüksek düzeyde olduğu belirlenmiştir. Buradan hareketle öğrencilerin e-öğrenme sürecinde başarılı olabilmeleri için bilgisayar öz-yeterliklerini ve e-öğrenmeye yönelik motivasyonlarını artırmaya yönelik çalışmalar yapılması yararlı olacaktır. Öğrencilerin e-öğrenmeye 
yönelik motivasyon seviyelerini arttırmak için derslerde öğrencilerine e-öğrenmenin yararları ve kullanım kolaylıklarından bahsedilebilir. Onların anlamlı ve faydalı e-öğrenme deneyimi yaşamalarına firsat oluşturulabilir. Orban, Teeling-Smith, Smith ve Porter'ın (2018) önerisi doğrultusunda çevrimiçi dersler ile yüz yüze dersler bir bakıma karma öğrenme şeklinde işlenebilir. Bu şekilde öğrenciler ilk başlarda alışık oldukları yüz yüze ortamlardan kopmayacak ve zamanla e-öğrenme ortamlarına alışacaklardır. Böylelikle bu öğrencilerin e-öğrenmeye yönelik motivasyon seviyeleri yükselebilecektir. Araştırmacılar öğrencilerin bilgisayar özyeterliklerinin artırılmasında eğitim desteğinin (Islam ve diğ., 2015) önemli olduğunu vurgulamaktadır. Öğrencilerin e-öğrenmeye yönelik motivasyonlarının artırılmasında ise e-öğrenmenin pedagojik boyutunun iyileştirilmesinin (Wang, Cowie ve Jones, 2008), eğitim kalitesinin yükseltilmesinin (Al-Masaud ve Gawad, 2014), teknolojiye yönelik tutumlarının olumlu yönde geliştirilmesinin (Nawaz ve Qureshi, 2010), e-öğrenmede öğrenci-öğretmen etkileşiminin nicelik ve niteliğinin artırılmasının (Rezaei Mood, 2006) ve öğrenenlere ihtiyaç duyulduğunda teknik destek sağlanabilmesinin (Nawaz ve Qureshi, 2010) önemli olduğu belirtilmektedir. Bu bağlamda kurumlar öğrencilerin e-öğrenmeye yönelik hazır bulunuşluklarının iyileştirilmesinde bu önlemleri dikkate almalıdır.

Cinsiyet değişkenine göre e-öğrenmeye hazır bulunuşluk puan ortalamaları arasında farklılıkların erkek öğrenciler lehine olduğu görülmektedir. Alanyazında bu durumu destekler nitelikte çalışmalar bulunmakta olup, erkek öğrencilerin hem teknolojiye hazırbulunuş olarak, hem de etkili kullanıcı olarak daha iyi durumda olduğunu göstermektedir (Jackson ve diğ., 2008; Torkzadeh ve Van Dyke, 2002). Bu nedenle kadın öğrencilerin e-öğrenmeye yönelik hazır bulunuşlarını yükseltmek için çalışmalar yapılması yararlı olacaktır. Bununla birlikte, fiziki ortam ve ek oturumlar/kurslar düzenlenerek kadın öğrencilere yönelik kurumsal önlemler alınabilir. Ayrıca kurumsal olarak kullanılan öğrenme yönetim sistemleri uyarlanabilir öğrenme bağlamında esnek hale getirilerek, kişiselleştirilmiş öğretim yapılmaya olanaklı hale getirilebilir. Son sınıftaki öğrencilerin e-öğrenmeye hazır bulunuşluk düzeylerinin, birinci sınıftaki öğrencilerden istatistiksel olarak manidar derecede yüksek olduğu belirlenmiştir. Bu bulguyu doğrular şekilde Yurdugül ve Demir (2017) tarafindan yapılan araştırmada da son sınıfta öğrenim gören öğrencilerin birinci sınıftaki öğrencilere göre e-öğrenmeye hazır bulunuşluklarının istatistiksel olarak daha yüksek olduğu belirlenmiştir. Bu durum öğrencilerin ara sınıflarda teknoloji destekli dersler aldıklarından kaynaklanabilir. Orban ve diğerlerinin (2018) çalışmalarında da, dikey entegre biçimde verilen teknoloji derslerinin öğrencilerin teknolojiye ilişkin hazır bulunuşluklarını ve okuryazarlıklarını artırdığı belirlenmiştir. Bu nedenle birinci sınıftaki öğrencilerin e-öğrenmeye hazır bulunuşlarını yükseltmek adına birinci sınıf verilen bilişim derslerinin sayısının ve niteliğinin geliştirilmesine yönelik çalışmalar yapılabilir. Fakülteler ve yüksekokullar bazında da öğrencilerin e-öğrenmeye hazır bulunuşluk düzeyleri arasında manidar farklılıklar olduğu görülmektedir. Bu farkın öğretim programında yer alan teknoloji destekli derslerden kaynaklanıyor olabilir. Bu durum ayrıntılı biçimde çalışılmalıdır. Bazı bölümlerin öğretim programlarında bilişim teknolojisi derslerine hiç yer verilmediği görülürken, bazı bölümlerin programlarında ise her sınıf seviyesinde teknoloji destekli derslere yer verildiği görülmektedir. Bu nedenle öğretim programlarının yapılandırılmasında teknoloji destekli derslere yer verilmesinin, bunun birinci sınıf ağırlıklı olmak üzere her sınıf seviyesinde verilmesinin yararlı olabileceği ifade edilebilir. Bu bulguyu doğrular şekilde Yurdugül ve Demir (2017) tarafindan yapılan araştırmada da öğrenim görülen bölüme göre öğrencilerin e-öğrenmeye hazır bulunuşluk düzeyleri arasında manidar farklılıklar olduğu belirlenmiş̧tir. E-öğrenmeye düşük düzeyde hazır olduğu tespit edilen programların öğrencilerinin e-öğrenmeye hazır bulunuşluk seviyelerini yükseltmek için uygulamalı bilgisayar ve internet okuryazarlı̆̆ kursları düzenlenebilir, bu kapsamda seçmeli dersler verilebilir. Eğitim fakültelerinde verilmekte olan teknolojinin eğitime entegrasyonuna dair dersler diğer fakülte ve yüksekokullarda da verilerek, bu derslerin niteliği ve sayısı arttırılabilir.

$\mathrm{Bu}$ araştırma üniversite öğrencilerinin e-öğrenmeye hazır bulunuşluklarını üniversite genelinde araştırması ve eöğrenmeye yönelik hazır bulunuşlukla ilgili araştırma sonuçlarının genellenebilirliğine katkı sağlanabilmesi açısından önemlidir. Araştırmada fakülte/yüksekokul bazında birimlerdeki öğrencilerin e-öğrenmeye hazır bulunuşlukları karşılaş̧ırılmış olup, araştırma sonuçları birim bazında bir ihtiyaç analizi raporu ortaya koymaktadır. Bu bağlamda ilgili birimlerin öğretim programlarında öğrencilerin ihtiyaçlarına yönelik güncellemeler yapmak, alt yapı olanaklarını iyileştirmek, öğrencilerin hazır bulunuşluklarının artırılması açısından gereklidir. Bu bağlamda araştırma sonuçlarının uygulayıcılar ve karar alıcılar tarafından dikkatle ele alınarak, ihtiyaca yönelik önlemler alınmalıdır. 


\section{Kaynakça/References}

Agbo, I. S. (2015). Factors influencing the use of information and communication technology (ICT) in teaching and learning computer studies in ohaukwu local government area of ebonyi state-nigeria. Journal of Education and Practice, 6(7), 71-86.

Akaslan, D. \& Law, E. L. C. (2011). Measuring teachers' readiness for e-learning in higher education institutions associated with the subject of electricity in Turkey. In Proceedings of 2011 IEEE Global Engineering Education Conference: Learning Environments and Ecosystems in Engineering Education (pp. 481-490). Amman, Jordan.

Akimanimpaye, F. \& Fakude, L. P. (2015). Attitudes of undergraduate nursing students towards e-learning at the University of the Western Cape, South Africa: teaching and learning in health care professions. African Journal for Physical Health Education, Recreation and Dance, 21(1), 418-433.

Al-Fraihat, D., Joy, M., \& Sinclair, J. (2017, June). Identifying success factors for e-learning in higher education. In ICEL 2017-Proceedings of the 12th International Conference on e-Learning (p. 247). Academic Conferences and Publishing Limited.

Allen, I. E. \& Seaman, J. (2013). Changing course: ten years of tracking online education in the United States. USA: Sloan Consortium.

Al-Masaud, K. A. \& Gawad, A. M. A. (2014). Impediments of activating E-learning in higher education institutions in Saudi Arabia. (IJACSA). International Journal of Advanced Computer Science and Applications, 5(4), 12-18.

Almunawar, M. N., Anshari, M., Susanto, H., \& Chen, C. K. (2015). Revealing customer behavior on smartphones. International Journal of Asian Business and Information Management, 6(2), 33-49 doi:10.4018/JJABIM.2015040103

Ambient Insights (2016). The 2015-2020 Worldwide self-paced elearning market: premium edition. http://www.ambientinsight.com/Reports/eLearning.aspx adresinden elde edildi.

Ansong, E., Lovia Boateng, S., \& Boateng, R. (2017). Determinants of e-learning adoption in universities: evidence from a developing country. Journal of Educational Technology Systems, 46(1), 30-60 doi: $10.1177 / 0047239516671520$

Asaari, A. H, Hasmi, M., \& Karia, N. (2005, June). Adult learners and e-learning readiness: a case study. 2005 European College Teaching \& Learning Conference, Athens, Greece.

Arpaci, I. (2015). A comparative study of the effects of cultural differences on the adoption of mobile learning. British Journal of Educational Technology, 46(4), 699-712 doi:10.1111/bjet.12160

Attis, D., Koproske, C., \& Miller, C. (2012). Understanding the MOOC trend: The adoption and impact of massive open online courses. Washington, DC: The Education Advisory Board. http://www.eab.com adresinden elde edildi.

Burd, E. L., Smith, S. P., \& Reisman, S. (2015). Exploring business models for MOOCs in higher education. Innovative Higher Education, 40(1), 37-49 doi:10.1007/s10755-014-9297-0

Choucri, N. et al. (2003). Global e-readiness for what? http://ebusiness.mit.edu/research/papers/177_choucri_global_ereadiness.pdf adresinden elde edildi.

Creswell, J. W. (2009). Research design: Qualitative, quantitative, and mixed methods approaches (Third Edition). USA: Sage Publications.

Darab, B. \& Montazer, G. A. (2011). An eclectic model for assessing e-learning readiness in the Iranian universities. Computers \& Education, 56(3), 900-910 doi: 10.1016/j.compedu.2010.11.002

Esterhuyse, M. \& Scholtz, B. (2015). Barriers to e-learning in a developing country: An explorative study. In Paper presented at the 9th IDIA conference, IDIA2015. Nungwi: Zanzibar. 
Gerlich, R. N., Browning, L., \& Westermann, L. (2010). The social media affinity scale: implications for education. Contemporary Issues in Education Research, 3(11), 35-42.

Goh, P. S. (2016). eLearning or technology enhanced learning in medical education-Hope, not hype. Medical Teacher, 38(9), 957-958 doi:10.3109/0142159X.2016.1147538

Harman, G. ve Çelikler, D. (2012). Eğitimde hazır bulunuşluğun önemi üzerine bir derleme çalışması. Eğitim ve Öğretim Araştırmaları Dergisi, 1(3), 147-156.

Haznedar, Ö. ve Baran, B. (2012). Eğitim fakültesi öğrencileri için e-öğrenmeye yönelik genel bir tutum ölçeği geliştirme çalışması. Eğitim Teknolojisi Kuram ve Uygulama, 2(2), $42-59$.

Hew, K. F. \& Cheung, W. S. (2014). Students' and instructors' use of massive open online courses (MOOCs): Motivations and challenges. Educational Research Review, 12, 45-58 doi:10.1016/j.edurev.2014.05.001

Hung M. L., Chou C., Chen C. H., \& Own Z. Y. (2010). Learner readiness for online learning: scale development and student perceptions. Computers \& Education, 55(3), 1080-1090 doi:10.1016/j.compedu.2010.05.004

Islam, N., Beer, M., \& Slack, F. (2015). E-learning challenges faced by academics in higher education: A literature review. Journal of Education and Training Studies, 3(5), 102-112.

Jackson, L. A. et al. (2008). Race, gender, and information technology use: The new digital divide. CyberPsychology \& Behavior, 11(4), 437-442 doi:10.1089/cpb.2007.0157

Karaoğlan Yılmaz, F. G. (2016). Examining self directed learning with technology based on different learning approaches. Presented at the International Academic Conference on Teaching, Learning and E-learning, Budapest.

Karaoğlan Yılmaz, F. G. ve Çakmak, E. K. (2016). Internet-specific epistemological beliefs and online information searching strategies of pre-service teachers: Gender and department differences. Participatory Educational Research, 3, 63-80 doi:10.17275/per.16.10.3.2

Karaoğlan Yılmaz, F. G., Dilen, A., \& Durmuş, H. (2018). Lise öğrencilerinin mobil öğrenme araçlarını kullanma öz-yeterlik düzeylerinin incelenmesi. SDU International Journal of Educational Studies, 5(1), 112.

Kaur, K., \& Abas, Z. W. (2004, November-December). An assessment of e-learning readiness at the open university Malaysia. Paper presented at the International Conference on Computers in Education (ICCE2004), Melbourne, Australia.

Kaymak, Z. ve Horzum, M. B. (2013). Relationship between online learning readiness and structure and interaction of online learning students. Educational Sciences: Theory and Practice, 13(3), 1792-1797 doi:10.12738/estp.2013.3.1580

Keser, H., Karaoglan Yilmaz, F. G. ve Yilmaz, R. (2015). TPACK competencies and technology integration self-efficacy perceptions of pre-service teachers. Elementary Education Online, 14(4), 1193-1207 doi:10.17051/io.2015.65067

Limayem, M. \& Cheung, C. M. (2008). Understanding information systems continuance: the case of Internetbased learning technologies. Information \& Management, 45(4), 227-232 doi:10.1016/j.im.2008.02.005

Lopes, C.T. (2007). Evaluating e-learning readiness in a health sciences higher education institution. Proceedings of IADIS International Conference of E-learning, Porto, Portugal.

McConnell, D. (2017). E-learning in Chinese higher education: the view from inside. Higher Education, 1-15 doi:10.1007/s10734-017-0183-4

McGill, T. J., Klobas, J. E., \& Renzi, S. (2014). Critical success factors for the continuation of e-learning initiatives. The Internet and Higher Education, 22, 24-36 doi:10.1016/j.iheduc.2014.04.001 
Mirza, A. A. (2008). Students' perceived barriers to in class participation in a distributed and gender segregated educational environment. The Electronic Journal of Information Systems in Developing Countries, 35(1), 1-17. doi: 10.1002/j.1681-4835.2008.tb00244.x

Moftakhari, M. M. (2013). Evaluating e-learning readiness of faculty of letters of Hacettepe University. Unpublished master's thesis, Hacettepe University, Ankara.

Mulugeta, S. \& Buckley, S. (2015). Theoretical perspective: E-learning challenges and proposed framework in developing countries. In Paper presented at the 9th IDIA conference, IDIA2015. Nungwi: Zanzibar

Naresh, B. \& Reddy, B. S. (2015). Challenges and opportunity of E-learning in developed and developing countries: A review. International Journal of Emerging Research in Management \& Technology, 4(6), 259-262.

Nawaz, A. \& Qureshi, Q. A. (2010). Eteaching/Epedagogy threats \& opportunities for teachers in Heis. Global Journal of Management And Business Research, 10(9), 23-31.

Oliver, R. (2001). Assuring the quality of online learning in Australian higher education. In Wallace, M, Ellis, A, and Newton, D (eds). Proceedings of Moving Online II Conference, Southern Cross University, Lismore, NSW, pp. 222-231.

Orban, C. M., Teeling-Smith, R. M., Smith, J. R., \& Porter, C. D. (2018). A hybrid approach for using programming exercises in introductory physics. American Journal of Physics, 86(11), 831-838. doi:10.1119/1.5058449

Pannen, P. \& Abubakar (2005, August). Designing e-learning: shouldn't we be ready, Second International Conference on e-Learning for Knowledge-Based Society, Bangkok, Thailand.

Persico, D., Manca, S., \& Pozzi, F. (2014). Adapting the technology acceptance model to evaluate the innovative potential of e-learning systems. Computers in Human Behavior, 30, 614-622. doi:10.1016/j.chb.2013.07.045

Rezaei Mood, F. (2006). Challenges assessment and ways of implementing E-learning in Iran. Master Thesis, Sharif University of Technology, Iran.

Tarhini, A., Hone, K., Liu, X., \& Tarhini, T. (2017). Examining the moderating effect of individual-level cultural values on users' acceptance of E-learning in developing countries: a structural equation modeling of an extended technology acceptance model. Interactive Learning Environments, 25(3), 306-328. doi:10.1080/10494820.2015.1122635

Tekinarslan, E. (2008). Attitudes of Turkish distance learners toward internet based learning: an investigation depending on demographical characteristics. Turkish Online Journal of Distance Education, 9(1), 67-84. doi:10.17718/tojde.48868

Toomhirun, C. (2015). Attitude of Thai instructors and students toward a distance learning system for agricultural extension and development programs for participating in the ASEAN community. Mississippi State University.

Wang, S.-C., Cowie, B., \& Jones, A. (2008). Challenges of E-learning for University Instructors in Taiwan. In Paper presented at the The 16th International Conference on Computers in Education (ICCE 2008). Taipei, Taiwan

Yilmaz, R. (2017). Exploring the role of e-learning readiness on student satisfaction and motivation in flipped classroom. Computers in Human Behavior, 70, 251-260. doi: 10.1016/j.chb.2016.12.085

Yilmaz, R., Karaoglan Yilmaz, F. G., \& Cavus Ezin, C. (2018). Self-directed learning with technology and academic motivation as predictors of tablet pc acceptance. In Handbook of Research on Mobile Devices and Smart Gadgets in K-12 Education (pp. 87-102). IGI Global. 
Yılmaz, R., Sezer, B. ve Yurdugül, H. (2018). Üniversite öğrencilerinin bilgi ve iletişim teknolojilerinden yararlanma durumları ve alışkanlıkları üzerine bir araştırma: mevcut durum ve geleceğe bakış. Ege Eğitim Teknolojileri Dergisi, 2(1), 1- 18.

Yuan, L., \& Powell, S. (2013). MOOCs and disruptive innovation: Implications for higher education. In-depth, 33, 1-7.

Yurdugül, H. ve Demir, Ö. (2017). Öğretmen yetiştiren lisans programlarındaki öğretmen adaylarının eöğrenmeye hazır bulunuşluklarının incelenmesi: Hacettepe üniversitesi örneği. Hacettepe Üniversitesi Eğitim Fakültesi Dergisi, 32(4), 896-915. doi:10.16986/HUJE.2016022763 